\title{
Research on Protection and Inheritance Path of Toponym Culture in Xingqing District of Yinchuan City Based on Cultural Gene
}

\author{
LIU Ying ${ }^{1}$, WANG Rong ${ }^{2, *}$ \\ ${ }^{I}$ College of Tourism and Landscape Architecture Guilin University of Technology Guilin Guangxi 541000 China \\ *Corresponding author. Email: $984321752 @ q q . c o m$
}

\begin{abstract}
Place names are symbols of local regional culture and contain rich cultural connotations. On the basis of collecting the place names of Xingqing District and excavating the cultural elements of the place names of Xingqing District, this paper extracts the cultural genes of Xingqing District, takes the classification of cultural genes as the main body, excludes the two main structural genes, and selects the appropriate transmission channels according to the different attributes of cultural genes, and finally realizes the protection and inheritance of culture.
\end{abstract}

Keywords: cultural gene, place names, meme, inheritance, Xingqing District

\section{INTRODUCTION}

Xingqing district has a long history and rich cultural deposits, leaving many place names bearing its cultural changes. With the rapid development of urbanization, many old place names with rich cultural connotation in Xingqing District have been replaced by new names of "big, foreign and heavy", which makes the original distinctive place name culture of the region weaken continuously. Cultural genes have the special functions of screening, copying, spreading and protecting culture, and play an important role in the inheritance and development of culture. Therefore, from the perspective of cultural genes, this paper discusses the countermeasures for the inheritance and protection of geographical names in Xingqing District, which is of great significance for the continuation of historical context and the protection of geographical names in the process of rapid urbanization in Xingqing District.

\section{PLACE NAMES AND CULTURAL GENE}

\section{1 cultural gene}

"Gene" is originally a concept in biology, which is the material basis of heredity. It transmits the genetic information to the next generation through replication, transcription and translation, so that the offspring and the parents have similar characters. Cultural gene is a reference to the concept of "gene" in biology. Cultural gene means to copy the genetic information of regional customs and habits, thinking concepts, etc., and pass it on to future generations, so as to realize the continuation of regional culture. It is an important factor affecting the development and inheritance of regional culture [2].

\subsection{Cultural gene pedigree}

Through the collection, sorting and classification of cultural genes, the cultural gene genealogy is completed. In this paper, the cultured genes were divided into dominant and recessive types[3]. Dominant cultural genes mainly refer to those that describe natural landscapes, display geographical features and products of geographical entities, and can be directly presented to and perceived by people. However, hidden behind the cultural content and phenomena are often recessive cultural genes, which mainly reflect the local behavior, events, religious culture and thoughts and other humanistic resources

\subsection{Protection of place names and cultural genes}

As an important part of Chinese traditional culture, place-name culture mainly relies on the self-replication of cultural genes to realize its own protection and inheritance. Gene can be regarded as a part of the historical development of Xingqing District. This paper discusses the place names of Xingqing District in Yinchuan from the perspective of cultural genes, analyzes the main genes found in Xingqing District and selects the appropriate genetic path to protect the geographical name of cultural heritage in the process of rapid urbanization. 


\section{PLACE NAME CULTURE GENE DECOMPOSITION}

\subsection{The present situation of the research area and the general situation of place names}

Xingqing District has a long history and profound culture. The altitude is between 1010 and 1150 meters above sea level. The ground slope is about 2\%o. Xingqing District is a county-level municipal district established by Yinchuan in 1970. The original urban area of Yinchuan covers an area of 828 square kilometers, with a permanent resident population of 740,000 (2016). Xingqing area is a multi-ethnic area with 42 ethnic minorities and a population of more than 140,000 , of which 127,778 are Hui, accounting for $18.32 \%$ of the total population. Chengtian Temple Tower, Jade Pavilion, Zhongshan Park, Tanglai Park, Lijing Lake Park and other scenic spots.By analyzing the data of the second geographical place survey, it is found that the number of geographical names in Xingqing District, from high to low, is: unit, residential area, facilities, road, street, public transport station, mass autonomous organization, cultural tourism resources, physical geographical entity and administrative area. Different types of place names play different roles in inheriting regional culture. The place names such as residential area, street lane and cultural tourism resources are the main aspects reflecting regional culture, while the place names of units are randomly named and have little relationship with regional culture.

\subsection{The establishment of geographical name culture gene pedigree in Xingqing District}

This paper mainly analyzes the geographical names such as administrative regions, residential areas, streets and lanes, mass autonomous organizations, cultural tourism resources, and physical geographical entities (due to the random naming of unit geographical names and the insufficient significance of geographical names, this study does not make an in-depth analysis of such geographical names). These place names contain cultural elements of agriculture, religious belief, military war, folk customs, values, ethnic relations and other aspects. These place names are classified according to the dominant and the recessive, the former mainly includes the place names reflecting the natural characteristics, the way of production and life and so on. The cultural connotation of recessive place names is hidden behind place names. It is necessary to dig out its cultural connotation by referring to historical documents and field investigation.

\section{PLACE NAME CULTURE GENE AND TIS EXPRESSION WAY}

Through the excavation and analysis of the cultural connotation of Xingqing District place-names, the cultural gene of Xingqing District is obtained, as shown in Figure 1 .

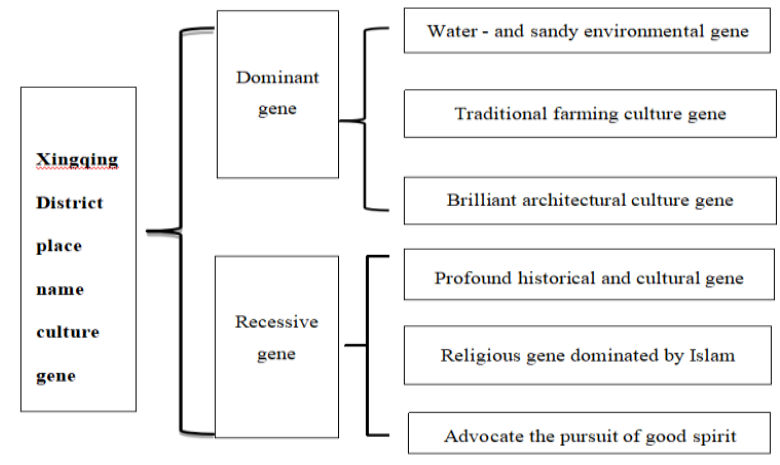

Figure 1 Cultural pedigree of Xingqing District place names

\section{ANALYSIS OF THE RELATIONSHIP BETWEEN CULTURAL GENE TYPES AND GENETIC PATH}

The division and judgment of gene types are the connection between cultural genes and genetic path, and also the premise for selecting appropriate genetic path (as shown in Figure 1)[4]. This paper follows the following principles :(1) whether to dominate the regional cultural attributes; (2) whether the inheritance is stable; (3) Whether it is widely used in the naming of various geographical names. At present, the types of cultural genes are divided, and geographical names in Xingqing region are divided into subject genes and non-subject genes. Through to the Xingqing District according to the analysis of the related literature and data and place names: Xingqing District has a "historical and cultural city" the laudatory name, it has a long history and rich cultural connotation, and in all kinds of cultural gene, the historical and cultural gene conversion rate is the highest, significant cultural status and the Xingqing District now has had a profound effect, for all kinds of place is Xingqing District cultural gene dominant culture; Similarly, water - and sandy environmental gene 、 traditional farming culture gene, brilliant architectural culture gene、 advocate the pursuit of good spirit、religious gene dominated by Islam also have certain influence on Xingqing District place names, which are all additional genes carrying Xingqing District cultural symbols, as shown in Figure 2. 


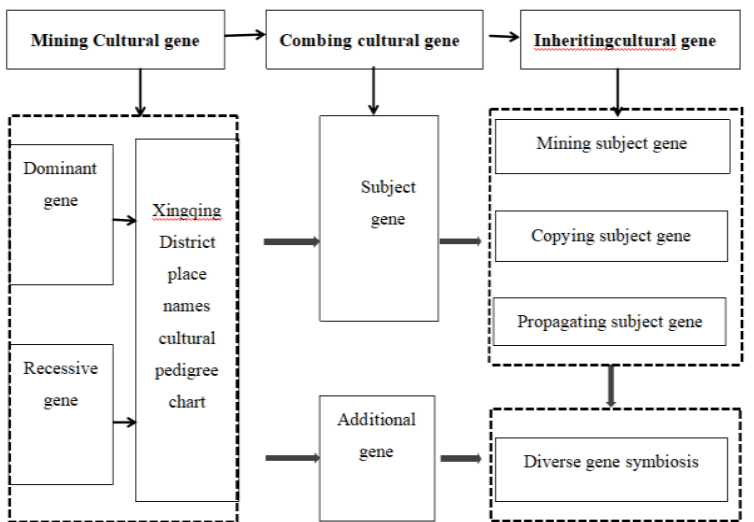

Figure 2 Cultural gene inheritance path chart

\section{RESEARCH ON THE PROTECTION AND INHERITANCE PATH OF CULTURAL GENE}

\subsection{Protection and development of the subject gene}

In order to ensure the sustainable development and benign inheritance of the host gene, there are several ways to choose the protection and genetic path:

(1) Subject culture gene mining.As cultural symbols representing geographical entities, place names contain important historical and cultural information, which are often an important part of Traditional Chinese culture and sometimes even the spiritual core [5]. With the rapid development of social economy in Xingqing District, a large number of historical place names have disappeared and changed, which is mainly related to the failure of Xingqing District to fully and deeply excavate the cultural place names of ancient cities and to establish a detailed database of cultural place names of ancient cities. Xingqing District should set up the folk place name culture research association led by the government to deeply dig the cultural connotation of place names, and record the valuable cultural place names of ancient cities, to ensure that no valuable cultural place names of ancient cities disappear at will.

(2) Replication of the main cultural gene.Memes copy refers to the reproduction of some historical culture that has disappeared or is about to disappear in some way. The replication of cultural gene in place names is to re-use some valuable cultural place names of ancient cities according to regional historical and cultural characteristics. Xingqing District of Yinchuan has a long history and rich cultural relics. It is of great significance to protect and develop these precious cultural resources of place names. For the replication of the main cultural genes in Xingqing District, the historical and cultural place-names excavated and arranged above can be classified according to their respective attributes, and then appropriate replication paths can be adopted.

(3) Publicity of the main cultural gene. Place names serve the people and are closely related to their production and life. Since many places were formed many years ago, the new generation of residents do not know the origin of place names and the historical and cultural connotation behind them, nor do they know the genetic protection value of the main culture, so the main protection of place names in Xingqing District needs the participation of genes.

\subsection{Symbiosis of diverse cultural genes}

The existence of diverse genes can effectively maintain the ecological balance of regional cultural system and regional cultural diversity. Therefore, non-subject genes are also an important part of place name memes, which cannot be changed or destroyed at will. Planners should adopt a "symbiotic" attitude towards diverse memes. Cultural gene symbiosis refers to the coexistence of cultural genes of different periods, connotations and types in a specific environmental space for harmonious symbiosis without damaging the overall features and losing their original functions.

\section{CONCLUSION}

Xingqing District has a long history, leaving a lot of places with rich cultural connotations, the place names of these places carry the contents of natural culture, historical culture and social culture of Xingqing District.Through carding culture gene, Xingqing District place cultural genes can be divided into main body gene, the additional gene.Subject genes are protected and inherited by means of mining, copying and publicity. For non-subject genes, a diversified and symbiotic attitude is adopted in the selection of inheritance paths, which not only improves their material carriers, but also inherits their internal spirits. This paper introduces the concepts and principles of cultural genes into the protection of place name culture in Xingqing District, hoping to provide reference and guidance for the protection, development and inheritance of place name culture in Xingqing District from the perspective of biogenetics.

\section{ACKNOWLEDGMENT}

Thanks for the help of the fund: The National Social Science Foundation of China Western Project: Research on the Protection and Development of Cultural Heritage of Geographical Names in Lingnan Area under the Background of Urbanization. (No.17XSH006). 


\section{REFERENCES}

[1] H. Feng. Xingqing historical dialect [M]. Yinchuan: Ningxia People's Publishing House, 2012.

[2] H.Zhao, J.Wang. Genealogical map construction and inheritance path research of cultural genes__ A case study of ancient Yunnan cultural genes [J]. Modern City Research,2014(05):90-97.

[3] S.feng, L.liu. Exploration of cultural genes in Hebei province based on geographical names $[\mathrm{J}]$. Journal of Hebei University of Geosciences, 2017, 40(04): 127-131+140.

[4] M.Bi ,Research on inheritance path of rural cultural genes [D]. Suzhou: Suzhou Institute of Science and Technology,2011.

[5] S.Wang. Reflections on the culture of place names [J]. Chinese place names,2018(06):4-5. 